This version may differ slightly from that found in M. Lacorte \& J. Leeman (Eds.). Español en Estados Unidos y en otros contextos de contacto: Sociolinguística, ideología y pedagogía. Madrid: Iberoamericana. 2009. 67-84. Please cite published version.

\title{
Intervocalic voiced stops in Yucatan Spanish: A case of contact-induced language change?
}

\author{
Jim Michnowicz \\ North Carolina State University
}

This study examines the possible role of language contact on the realization of $/ \mathrm{b} \mathrm{d} \mathrm{g} / \mathrm{in}$ Yucatan Spanish (YS). Whereas standard Spanish displays an alternation between stops [b d g] and fricatives $[\beta \delta \gamma]$, YS shows a preference for stops in contexts that would require a fricative in other varieties. The extended use of $[\mathrm{b} \mathrm{d} \mathrm{g]} \mathrm{in} \mathrm{YS} \mathrm{has} \mathrm{been} \mathrm{attributed} \mathrm{to} \mathrm{influence} \mathrm{from} \mathrm{the}$ contact language, Mayan, by some researchers (Nykl 1938, Mediz Bolio 1951, Lope Blanch 1987), while others prefer a language-internal explanation (Cassano 1977, Yager 1982). Therefore, the present study addresses the following research questions: Could the observed pattern for voiced stops be the result of language contact with Mayan? Is Mayan in a position to have influenced YS, thereby making a contact-based explanation plausible? Is there quantitative evidence of a link between speaking Mayan and higher rates of stop variants? Using the criteria established by Thomason (2001) for determining the possibility of contact-induced change, the study finds that there has been sufficient contact on both an individual and a societal level to warrant a contact-based explanation for [b d g]. Especially important was the previous trend to hire Mayan-speaking nannies in middle and upper class homes. Based on data from 40 sociolinguistic interviews, this study finds a significant effect for Mayan-Spanish bilingualism on the production of stops. Speakers over the age of 30, exposed to more Mayan and Mayaninfluenced Spanish, also produce significantly more stops. Based on data from this study and the presence of similar patterns in other bilingual regions, this study concludes that the higher rates of $[\mathrm{b} \mathrm{d} \mathrm{g]} \mathrm{in} \mathrm{YS} \mathrm{are} \mathrm{due} \mathrm{to} \mathrm{language} \mathrm{contact} \mathrm{via} \mathrm{shifting} \mathrm{second} \mathrm{language} \mathrm{(L2)} \mathrm{speakers} \mathrm{of} \mathrm{Spanish,}$ but not due to specifically Mayan influence on the dialect.

\section{Introduction}

The Spanish spoken in the southern Mexican state of Yucatan is a regional dialect in contact with an indigenous substrate language, Yucatec Mayan (hereafter 'Mayan'). Recent census data shows that $33.5 \%$ of the population reports speaking Mayan, a number that was much higher in previous decades (INEGI 2005). This study is designed to discover what role, if any, language contact between Mayan and Spanish has had on a well-documented feature of Yucatan Spanish (YS), namely the surface realization of the voiced stops /b d g/.

Standard Spanish displays an alternation between voiced stops and fricatives that is dependent on phonetic context; stop variants [b d g] arise following a pause or a nasal consonant, with the liquid /1/ also triggering a stop for /d/ (i.e., homorganic nasals and liquids). ${ }^{1}$ The fricative variants, [ $\beta \delta \gamma$ ], arise elsewhere (cf., Dalbor 1980, among many others). While most varieties of Spanish display this alternation, speakers of YS often produce stop [b d g] in contexts requiring the [+cont] variant in the standard language. Compare standard Spanish [be.ßo] and YS [be.bo]

\footnotetext{
${ }^{1}$ The literature consistently refers to these [+cont] variants as 'fricatives', although in most dialects (including YS) they are more appropriately classified as approximants (cf., Hualde 2005). Following the literature, in this article I will use the term 'fricative' to refer to any [+cont] (i.e., non-stop) realization.
} 
'bebo', (I drink). Taking into account only those tokens arising in non-neutralizing contexts, (e.g. following a pause or homorganic nasals or liquids), in the present study we find that [b] occurs with an overall frequency of $42 \%$, [d] 32\%, and [g] 28\%. Since tokens in neutralizing contexts are excluded, all of the realizations of $/ \mathrm{b} \mathrm{d} \mathrm{g/} \mathrm{analyzed} \mathrm{in} \mathrm{the} \mathrm{present} \mathrm{study} \mathrm{would} \mathrm{be} \mathrm{realized} \mathrm{as}$ fricatives in standard varieties of Spanish.

Early studies of the dialect tended to ascribe stop pronunciations, along with any other distinctive features of the dialect (cf., Lope Blanch 1987, Michnowicz 2006), to direct influence from the contact language, Mayan. For example, Barrera Vázquez (1937: 9) attributes the "peculiar entonación" of YS to Mayan influence, while Nykl (1938) notes that the most interesting contact-induced features are found in the phonology of the dialect, with the consonants of YS giving it an unmistakable sound, which he describes as "estar oyendo hablar en castellano a un comerciante alemán" (217). Mediz Bolio (1951) argues that YS is the product of a linguistic "mestizaje", and that "los yucatecos hablamos español con fonética maya, directamente impuesta..." (12,19). Lope Blanch (1987: 11) likewise proposes that the phonetics of Mayan has been transferred to Spanish. For example, he notes voiced stops as one possible case, stating "en [el español yucateco], la influencia de la lengua maya salta a la vista, y no puede ser motivo de discusión" (p. 9). Other studies, however, tend to stress language-internal development to explain the pattern of stops in the dialect. Alvar (1969) concludes that the dialect has evolved as part of the larger Mexican speech zone, in spite of the phonetic differences between YS and standard Mexican Spanish. Cassano (1977) and Yager (1982) both argue that, based on the similar stop patterns in some other varieties of Spanish, the Yucatan pattern is the result of processes internal to Spanish. ${ }^{3}$ Both authors do, however, admit the possibility of some indirect influence from Mayan on this feature, without specifying what such influence might look like. ${ }^{4}$

This paper seeks to provide quantitative and qualitative answers to this debate, by asking the following research question: Could the observed pattern for voiced stops be the result of language contact with Mayan? Two sub-questions follow: 1) Is Mayan in a position to have influenced YS, thereby making a contact-based explanation plausible? and 2) is there quantitative evidence of a link between speaking Mayan and higher rates of stop variants?, that is, is bilingualism a significant factor in the extended use of stops over fricatives? In order to offer an initial answer to these questions, the rest of the chapter is organized as follows: First I address the sociolinguistic context of Mayan in Yucatan, following the criteria proposed by Thomason (2001) to determine what role, if any, Mayan could have played in the development of YS. Next I explain the data collection and analysis methodology. Third I analyze the possibility through multivariate analysis (VARBRUL) that speaking Mayan significantly affects the production of stops $[\mathrm{b} \mathrm{d} \mathrm{g}]$ for speakers of the dialect. Age, another external factor that relates to the amount of contact a speaker has had with Mayan or Mayan-influenced Spanish throughout his/her lifetime, is also examined. Finally, I examine the possibilities of direct versus indirect influence of Mayan on YS, as well as, a discuss the data, and provide final conclusions.

\section{Sociolinguistic background and the status of Mayan in Yucatan}

As a first step in our analysis, this section seeks to determine the ability of Mayan to have influenced the dominant language (Spanish) in Yucatan. Thomason (2001: 93-95) provides a

\footnotetext{
${ }^{3}$ The extension of stops to non-standard phonetic contexts in other varieties of Spanish will be addressed in the discussion.

${ }^{4}$ See Lope Blanch (1987), Solomon (1999) and Michnowicz (2006) for a more thorough review of previous work on YS.
} 
series of tests that may be employed in cases of possible contact-induced language change, and that below we will apply to the question of voiced stops in YS. ${ }^{5}$

The first step in the determination of contact influence is whether the language in question shows multiple instances of change that could be related to contact, since if contact is sufficient to have affected one feature in a language, it is likely to have been sufficient to possibly affect other features as well (Thomason 2001: 93). YS does contain several phonetic features that have been attributed to Mayan, including utterance final [m], aspirated $/ \mathrm{p} \mathrm{t} \mathrm{k} /$, and the maintenance of hiatus via glottal stop insertion (cf., Yager 1982, Lope Blanch 1987, Michnowicz 2006), as well as intonation (Barrera Vázquez 1937, Nykl 1938, Mediz Bolio 1951). Likewise, there is an abundance of Mayan loan words in YS, which also attests to the close contact between the two languages (cf., Suarez 1945/1979, Barrera Vázquez 1937). In addition to the possible influence of Mayan on Spanish, we find further proof of close Mayan-Spanish contact in the influence of Spanish on the indigenous language. For example, in modern spoken Mayan, Spanish numbers are used when counting higher than four (Bolles \& Bolles 2001), these having replaced the indigenous numerals. Mayan-speakers in the present study refer to their language as 'la mestizada' or 'la reformada', instead of 'la legítima maya', used by these speakers to describe an older version of the language uncontaminated by contact with Spanish. Although the difference in prestige between the two languages undoubtedly plays a role in the possible transfer of features, Mayan does enjoy a level of social recognition which is unusual for indigenous languages in Latin America, and is spoken at all levels of society (Lope Blanch 1987: 8-10). As such, Mayan may have been able to exert more linguistic influence on Spanish than other indigenous languages of Mexico (Lope Blanch 1987).

Second, one must prove that there has been sufficient contact between the two languages to account for contact-induced change (Thomason 2001: 93). Colonial demographics and modern census data speak to the level of contact in Yucatan. Throughout the colonial period, the Spanishspeaking elite was vastly outnumbered by the Mayan-speaking majority, with Spaniards representing around one percent of the population in the decades following the conquest (Mosely 1980: 102). Even on the eve of independence at the turn of the $19^{\text {th }}$ century, people of European descent comprised only $28 \%$ of the population, with the majority made up of Mayan-speaking natives (p. 104). While present day demographics have changed considerably, Yucatan still contains a large number of Mayan-speakers, with $33.5 \%$ of the population reporting that they speak an indigenous language (i.e., Mayan) in the 2005 census (INEGI 2005). In addition to this centuries-long contact throughout the peninsula, an increase in urbanization from the end of the $19^{\text {th }}$ century has brought the two populations into close contact within cities such as Merida, where many older residents report being raised in part by Mayan-speaking nannies (cf., Michnowicz 2006). Several participants in the present study spoke of this trend during their interviews, including this middle-aged woman speaking about her uncle: “...ese nene [mi tío] lo crió una nana, una mestiza, y hasta ahorita mi tío Alfredo habla la maya. ¿Por qué? Porque lo aprendió de su nana mestiza, hablaba más, la nana lo tenía más tiempo que su mamá y papá” (227F, 49, lawyer) And here an older woman notes the previously common trend for many rural, Mayan-speaking families to send their daughters to work with a Spanish-speaking family in the city:

...[decían]...'llévame a mi hija para que viva contigo. No tienes que pagarle'. En esa época, pues, querían que los hijos salieran, entonces desde muy chiquita las mesticitas venían a las casas y no hablaban nada de español. Sólo, sólo maya. Entonces a nosotros nos enseñaban porque, yo no sé maya, pero muchas cosas entiendo...(105F, 60, ret. business owner)

\footnotetext{
${ }^{5}$ Note that Lass (1997), a critic of contact theories of language change, proposes very similar criteria (p. 207).
} 
As these quotes suggest, older, monolingual speakers of Spanish were often exposed to Mayan or Mayan-influenced Spanish on a daily basis from a very early age. The contact between Spanishand Mayan-speakers took place not only in the markets or the streets, but also in the speakers' homes. In the case of YS, then, there appears to have been sufficient contact on both societal and individual levels to sustain the possibility of contact-induced change.

Next one must determine that the proposed contact feature exists in the languages in question and that the pattern for the feature can be accounted for by language contact (Thomason 2001: 93-94). An examination of the phonemic inventory of Mayan shows that neither the voiced stops [b d g] nor the voiced fricatives $[\beta \delta \gamma] \square$ are present natively in that language (cf., Ola Orie \& Bricker 2000: 311). ${ }^{6}$ Therefore, it is clear that any possible Mayan influence on this feature of YS cannot be the direct transfer of a segment, but rather may be a case of indirect influence, or what Thomason and Kaufman (1988: 38) call "imperfect learning". This phenomenon can arise when a large group of speakers shifts over time, via (partial) bilingualism, to the target language (here, Spanish), bringing with them fossilized features of L2 acquisition that may eventually spread to the monolingual population (p. 38-42), a possibility that will be addressed further later in this chapter.

Spanish did, of course, have all three voiced stops prior to contact with Mayan, so the pattern in YS is either the extension of already existing segments to contexts outside of panHispanic norms, or the preservation of an archaic feature that subsequently changed in other dialects (cf., Canfield 1981). One question, therefore, is whether Spanish contained the present stop-fricative alternation at the time it was introduced to the Yucatan peninsula. Some evidence suggests that the fricatives already existed in complimentary distribution in the $16^{\text {th }}$ century (Lipski 1994: 27), and Penny (2002: 76) notes that the change $/ g />[\gamma]$ had already occurred in the $13^{\text {th }}$ century. Canfield (1981), however, while noting that the alternation existed since the Middle Ages, attributes the preference for stops in some Latin American dialects to archaism, with the fricative variants becoming dominant in Spanish after those regions were already colonized and their respective linguistic patterns in place (p. 3-6). Either way, contact influence remains a possibility, as shifting Mayan-speakers likely would not have perceived the alternation whenever it arose. These bilingual speakers therefore could have played a role in either preserving an archaic feature of the dialect, or in reducing the scope of an extant monolingual pattern with a simplified pattern that prefers occlusives in some phonetic contexts.

Finally, one must examine possible language-internal motivations for the change in question (Thomason 2001: 94). In this case, the trend across Spanish dialects (and Romance varieties in general) is the weakening of consonants, and many varieties of Spanish elide $/ \mathrm{b} \mathrm{d} \mathrm{g/to}$ such an extent that they are deleted (cf., Canfield 1981, Lipski 1994, Posner 1996). Thus, while not impossible, it is improbable that YS extended its use of stops based solely on internal factors, since doing so would place it apart from the current of Spanish and Romance around the world. Yager (1982) has noted, however, that there may be a general trend toward fortition in YS. If such a trend exists, it occurs with other segments that are also attributed to possible Mayan influence, i.e., aspirated stops and hiatus via glottal stop insertion. ${ }^{7}$ Still, the overall tendency in Spanish is the weakening of voiced stops/fricatives, suggesting that YS [b d g] have not developed entirely through language internal mechanisms.

To summarize, the answer to our initial question is yes, Mayan is in a position to have influenced the Spanish of Yucatan, albeit indirectly in the case of [b d g]. The sustained contact between YS and Mayan and the high rates of bilingualism throughout the past five centuries have

\footnotetext{
${ }^{6}$ Mayan contains a series of four voiceless stops (/p t k $\left.2 /\right)$ and six ejectives (/p' b' t' ф' č ' k'/). The only fricatives are /s š x h/ (Ola Orie \& Bricker 2000: 311).

${ }^{7}$ The possible role of fortition across YS is reserved for future research.
} 
created an environment conducive to inter-language influence, that when combined with the exposure of monolingual speakers of Spanish to Mayan-speaking nannies and domestic workers allows for a possible contact explanation. Of course, the fact that Mayan 'could' have influenced YS does not necessarily mean that it did. If language contact is in part responsible for the use of stops in YS, one would expect a higher frequency of stop use among bilingual (Spanish-Mayan) speakers, as well as among those exposed to more Mayan or Mayan-influenced Spanish. In order to address this possibility, what follows will detail analyses of data collected for the present study, in order to determine what statistical relationship, if any, there is between speaking Mayan and the production of stops [b d g].

\section{Methodology}

Data for the present study consist of 40 sociolinguistic interviews carried out by the author over a two month period in Merida, the capital of the state of Yucatan. The corpus contains 8809 tokens of /b/, 12,244 of /d/, and 2976 of /g/, all in non-neutralizing contexts (i.e., not following nasals, a pause or $/ 1 /$ for $/ \mathrm{d} /$ ). In order to test the research question outlined above, two social factors are examined here. First, the possible role of bilingualism is tested by analyzing speakers belonging to two language groups (either monolingual speakers of Spanish or bilingual Mayan-speakers). Of the speakers studied here, 21 speak at least some Mayan and 19 are monolingual speakers of Spanish-. Thirteen of the 21 Mayan-speakers are fluent speakers of the language, and use Mayan in everyday interactions with their families. The remaining 8 speakers in this group can be considered passive speakers, representing a shifting generation defined as those whose parents or grandparents speak Mayan, and who can at least understand a conversation in that language, even though they may respond in Spanish. ${ }^{8}$ Also, since older speakers reported increased contact with native Mayan-speakers throughout their lifetimes (i.e., with nannies and domestic workers), age is also examined as a factor. Speakers were selected according to three age groups (19-29 $n=11,30-49 n=13,50+n=16)$ representing the distinct life stages of young adulthood, middle age, and old age. In the present study, middle aged and older speakers generally report being exposed to Mayan as children both at home (via nannies or family members) and throughout the city (via market workers, street vendors, etc.), while younger speakers describe growing up in a much more Spanish-dominant environment. No younger speakers, for example, reported having a Mayan-speaking nanny in their home. The hypothesis for this analysis is that if contact with Mayan has played a role in the stop pattern in YS, bilingual speakers and older speakers, exposed to more Mayan, will show an increased use of stops. If, however, language contact is not an important factor, the results will show no correlation between bilingualism/age and stop production, and the social forces driving this pattern will need to be sought elsewhere.

In the statistical analysis that follows, the dependent variable is the realization of $/ \mathrm{b} \mathrm{d} \mathrm{g} /$ in non-neutralizing contexts, coded as either [+cont] or [-cont]. The independent variables (factor groups) as outlined above are knowledge of Mayan and speaker age. For all dependent variables, first, an initial one-level binomial run established the weights for each factor group. This was followed by an up/down binomial analysis in order to determine the significance of these factors

\footnotetext{
${ }^{8}$ Separate up/down analyses found no significant difference between passive and fluent Mayan-speakers for $/ \mathrm{d} /$ and $/ \mathrm{g} /$. The difference between the two Mayan language groups was significant for $/ \mathrm{b} /$, with more [b] among passive speakers. As will be discussed later, [b] also occurs more frequently among middle-aged monolingual speakers of Spanish, and is the variable that shows the highest frequency of occlusion across the data. These facts are addressed further in the chapter. For the purposes of consistency, the present analysis will proceed with a combined Mayan-language factor group for all variables.
} 
to stop production in YS. In VARBRUL analyses, a factor weight of $>0.5$ indicates a positive effect for that factor.

\section{Data analysis and results}

The present analysis demonstrates that YS stops are sensitive to both linguistic and extralinguistic factors. A multivariate statistical analysis was run using GoldVarb 2001 (Robinson et al. 2001) in order to determine the role of each of the independent variables outlined above on the presence of stops in non-neutralizing contexts. ${ }^{9}$ Results of the analysis are found in Tables 1, 2, and 3.

Table 1

VARBRUL results for linguistic and social factors, stop [b]

\begin{tabular}{ccccc} 
Factor groups & Factors & $\%$ stop & $N$ & FW \\
\hline Preceding segment & Consonant & $51 \%$ & $562 / 1089$ & 0.596 \\
& Vowel & $41 \%$ & $3170 / 7720$ & 0.486
\end{tabular}

$\begin{array}{ccccc}\text { Following segment } & \text { Consonant } & 41 \% & 706 / 1711 & * 0.512 \\ & \text { Vowel } & 42 \% & 3026 / 7098 & * 0.497\end{array}$

$\begin{array}{ccccc}\text { Language } & \text { Span only } & 41 \% & 2033 / 4873 & 0.487 \\ & \text { Mayan } & 43 \% & 1699 / 3936 & 0.516\end{array}$

\begin{tabular}{ccccc} 
Age & $19-29$ & $30 \%$ & $618 / 2006$ & 0.377 \\
& $30-49$ & $44 \%$ & $1235 / 2764$ & 0.519 \\
$50+$ & $46 \%$ & $1879 / 4039$ & 0.549 \\
\hline
\end{tabular}

Note: all factors significant at .05 level unless otherwise indicated by $*$

Chi-square per cell: [b] 1.9911.

\footnotetext{
${ }^{9}$ Again, tokens following nasal consonants (or /l/ for [d]) were not counted in this analysis.
} 
Table 2

VARBRUL results for linguistic and social factors, stop [d]

\begin{tabular}{ccccc}
\hline Factor groups & Factors & $\%$ stop & $N$ & FW \\
& & & & \\
\hline Preceding segment & Consonant & $38 \%$ & $789 / 2065$ & 0.571 \\
& Vowel & $30 \%$ & $3086 / 10179$ & 0.486 \\
& & & & \\
Following segment & Consonant & $22 \%$ & $90 / 405$ & 0.396 \\
& Vowel & $31 \%$ & $3785 / 11839$ & 0.504 \\
& & & & \\
Language & Span only & $26 \%$ & $1711 / 6520$ & 0.440 \\
& Mayan & $37 \%$ & $2164 / 5724$ & 0.568 \\
& & & & \\
Age & $19-29$ & $21 \%$ & $603 / 2831$ & 0.369 \\
& $30-49$ & $39 \%$ & $1583 / 4017$ & 0.558 \\
& $50+$ & $31 \%$ & $1689 / 5396$ & 0.527 \\
\hline
\end{tabular}

Note: all factors significant at .05 level unless otherwise indicated by $*$

Chi-square per cell: [d] 1.9784.

Table 3

VARBRUL results for linguistic and social factors, stop [g]

\begin{tabular}{ccccc} 
Factor groups & Factors & $\%$ stop & $N$ & FW \\
& & & & \\
\hline Preceding segment & Consonant & $35 \%$ & $205 / 581$ & 0.588 \\
& Vowel & $26 \%$ & $633 / 2395$ & 0.478
\end{tabular}

$\begin{array}{ccccc}\text { Following segment } & \text { Consonant } & 34 \% & 171 / 500 & 0.567 \\ & \text { Vowel } & 26 \% & 667 / 1809 & 0.486\end{array}$

$\begin{array}{lclll}\text { Language } & \text { Span only } & 25 \% & 410 / 1615 & 0.452 \\ & \text { Mayan } & 31 \% & 428 / 1361 & 0.557\end{array}$

$\begin{array}{lllll}\text { Age } & 19-29 & 12 \% & 89 / 733 & 0.276\end{array}$

$30-49 \quad 33 \% \quad 323 / 971 \quad 0.548$

$50+\quad 33 \% \quad 426 / 1272 \quad 0.600$

Note: all factors significant at .05 level unless otherwise indicated by $*$

Chi-square per cell: [g] 1.4539 .

With regard to the linguistic factor of phonetic context, all three stop variants are significantly conditioned by the presence of a preceding (non-nasal) consonant. This finding agrees with previous research on other stop-preferring areas, such as Central America and the Andes (cf., Lipski 1994).

Although stops are preferred after consonants, they also occur following vowels, as indicated by the factor weights approaching 0.5 in Tables $1-3$. The difference between preceding 
vowel and consonant, however, was found to be significant for each of the three stops. With regard to the preceding consonant, stops are favored in particular by the presence of the liquids $/ \mathrm{r} /$ or $/ 1 /$, and the sibilant $/ \mathrm{s} /$, as determined by separate up/down analyses. ${ }^{10}$ The following segment was also found to be a significant conditioning factor for [d] and [g], but not for [b]. Results, however, are inconsistent, with [d] favored by a following vowel (as in lado), and [g] favored by a following consonant (as in grande). This result is interesting, given the tendency for /d/ to weaken or elide in many monolingual Spanish varieties (cf., Lipski 1994, Hualde 2005).

With regard to social factors, comparing monolingual speakers of Spanish and bilingual Mayan-speakers, we find a statistically significant trend for more stop production among bilinguals for all three variables $(\mathrm{p}=<.05)$. Monolingual speakers of Spanish, however, also produce stop variants, as indicated by the VARBRUL weights approaching 0.5, although less frequently than bilingual speakers. The difference between language groups is significant for all three variables, indicating that speaking Mayan is an important factor in the production of stops versus fricatives in YS.

Next, the age groups show a divide between the youngest speakers, who produce fewer stops (i.e. more fricatives), and middle-aged and older speakers, who produce more stops. The difference between speakers under 30 years of age and over 30 was found to be significant for all three variables. With regard to those over 30, separate up/down analyses showed that the differences between middle-aged and older speakers were significant only for $(d)(p=0.004)$; for (b) and (g) these speakers behave in a statistically identical manner $(\mathrm{p}=0.086$ and 0.916 respectively). Thus the important distinction here is if the speaker is older or younger than 30 . Importantly, older speakers as a group, both monolinguals and bilinguals, report being exposed to more Mayan-influenced Spanish, through increased contact with Mayan-dominant domestic workers, day laborers and others. An important example of this contact is the former practice in middle class families to hire indigenous nannies, who either spoke to the children in Mayan or in their Mayan-influenced L2 Spanish, a trend not found among younger speakers. Comparing the frequencies for each of the stops across age groups (apparent time - cf. Bailey2002) exemplifies the sharp reduction in stops among younger speakers of YS.

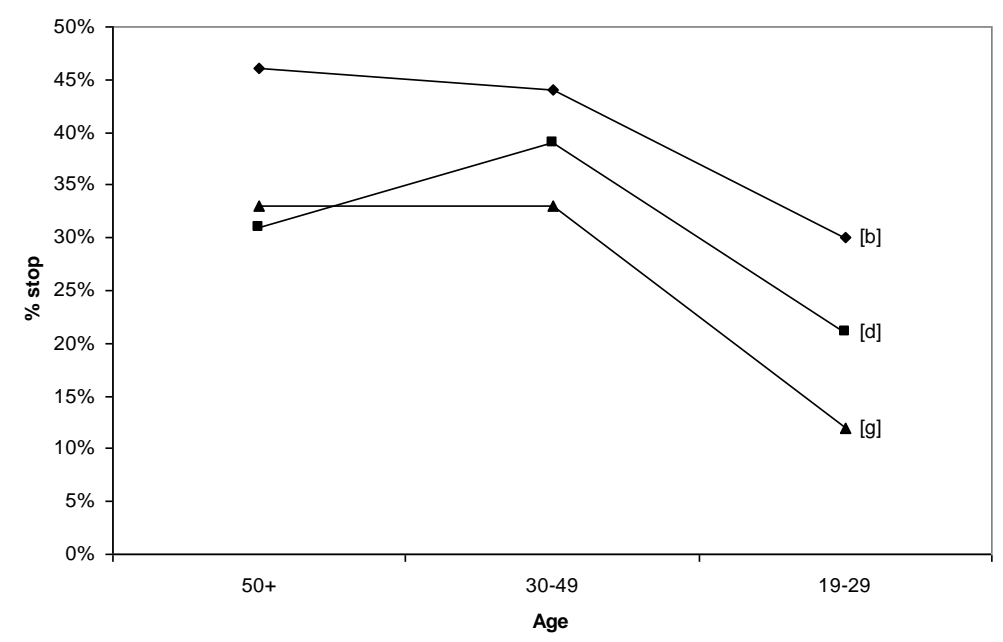

Figure 1. Frequencies of stop [b d g] in apparent time

\footnotetext{
${ }^{10}$ Cases of /d/ following /l/ were not counted in this analysis, as they constitute a neutralizing context for the dental stop/fricative.
} 
Next, in order to examine the interaction of age and language, an additional up/down analysis was run with combined factor groups (cross-tabulation). The results are seen in Tables 4, 5 , and 6.

Table 4

VARBRUL results for combined factor groups (cross-tab, stop [b] Factor groups \% stop $\quad N \quad$ FW

19-29

Spanish only

$27 \% \quad 285 / 1022 \quad 0.347$

19-29

Bilingual Mayan

$34 \% \quad 321 / 939 \quad 0.416$

$30-49$

Spanish only

$48 \% \quad 339 / 706 \quad 0.559$

30-49

Bilingual Mayan

$43 \% \quad 908 / 2103 \quad 0.510$

$50+$

Spanish only

$45 \% \quad 1279 / 2873 \quad 0.530$

$50+$

Bilingual Mayan $\quad 49 \% \quad 600 / 1202 \quad 0.577$

Note: all factors significant at .000 level

Chi-square per cell: 0.0001 
Table 5

VARBRUL results for combined factor groups (cross-tab, stop [d] Factor groups

19-29

Spanish only

$15 \% \quad 221 / 1432 \quad 0.290$

19-29

Bilingual Mayan

$25 \%$

$320 / 1275$

0.428

$30-49$

Spanish only

$30 \% \quad 331 / 1098$

0.491

$30-49$

Bilingual Mayan

$43 \% \quad 1314 / 3043 \quad 0.629$

$50+$

Spanish only

$29 \% \quad 1159 / 3990 \quad 0.478$

$50+$

Bilingual Mayan

$37 \% \quad 530 / 1406$

0.575

Note: all factors significant at .000 level

Chi-square per cell: 0.0001 
Table 6

VARBRUL results for combined factor groups (cross-tab, stop [g]

$\begin{array}{llll}\text { Factor groups } \quad \text { \% stop } \quad N W & \text { FW }\end{array}$

\begin{tabular}{lccc}
$\begin{array}{l}\text { 19-29 } \\
\text { Spanish only }\end{array}$ & $7 \%$ & $31 / 394$ & 0.193 \\
$\begin{array}{l}\text { 19-29 } \\
\quad \text { Bilingual Mayan }\end{array}$ & $17 \%$ & $58 / 339$ & 0.366 \\
$\begin{array}{l}\text { 30-49 } \\
\quad \text { Spanish only }\end{array}$ & $32 \%$ & $91 / 278$ & 0.576 \\
$\begin{array}{l}\text { 30-49 } \\
\quad \text { Bilingual Mayan }\end{array}$ & $33 \%$ & $232 / 693$ & 0.585 \\
$\begin{array}{l}\text { 50+ } \\
\text { Spanish only }\end{array}$ & $30 \%$ & $288 / 943$ & 0.552 \\
$\begin{array}{l}\text { 50+ } \\
\text { Bilingual Mayan }\end{array}$ & $41 \%$ & $138 / 329$ & 0.669 \\
\hline
\end{tabular}

Note: all factors significant at .000 level

Chi-square per cell: 0.0000

Results demonstrate that for all variables, factor weights for speakers under age 30 are < .05 , disfavoring stop production. For speakers over age 30, however, factor weights are $>.05$ for all groups but 2 (monolinguals for the variable [d]), thereby favoring stop production. Importantly, regardless of age, speaking Mayan correlates with a higher frequency of stops, with two exceptions: middle-aged Spanish monolinguals, who favor stop [b] (but not [d] and [g]) more than their Mayan-speaking counterparts, and middle aged speakers who produce approximately the same frequencies of stop [g] regardless of language (32-33\%). The difference for language group among middle aged speakers for $/ \mathrm{b} /$ was found to be significant in a separate up/down analysis (p. = 0.028). This is an interesting and unexpected result, given the correlation of MayanSpanish bilingualism and stop production for other cells in the cross-tabulation. This pattern may reflect the movement of speakers from Mayan backgrounds into the socio-economic mainstream that began in the last several decades, thereby exposing the monolingual population to increased Mayan-influenced Spanish (cf., Michnowicz 2006). Also important may be the fact that [b] is the variable with the highest rate of occlusion across the sample (42\%), and the lower frequency of occlusive [b] on the part of bilingual speakers may represent hypercorrection of the most frequent stop in YS. Further research is needed to address this possibility. Still, the overall trend seen in the present data is that speaking Mayan correlates with more stop variants, allowing us to conclude that Mayan-Spanish bilingualism is a contributing factor to stop production in this dialect. This trend, as well as the observed correlation between speakers age and stop frequency, is confirmed in Figure 2, which shows the average frequency of stops and fricatives for all three phonetic variables. We now turn our attention to how the Mayan language may have contributed to the observed pattern in YS. 


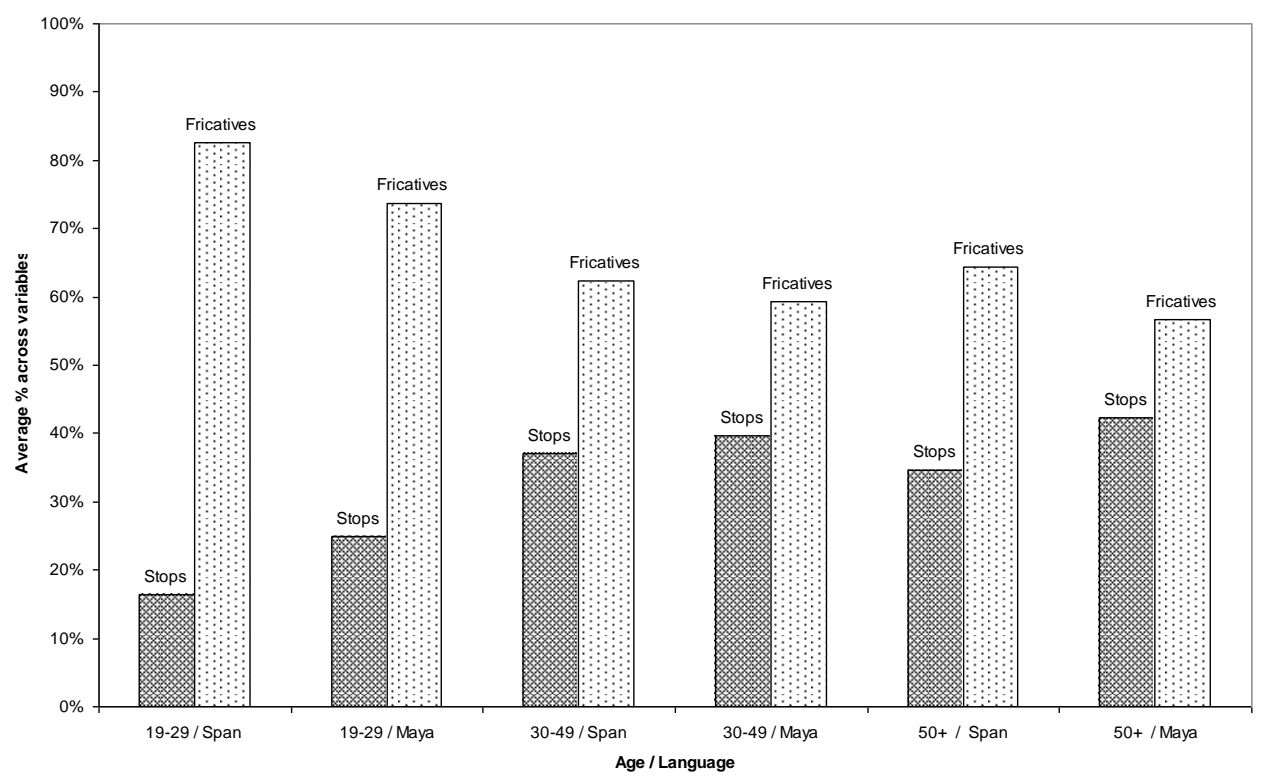

Figure 2. Frequencies of stop and fricative averaged across variants for cross-tabulation.

\section{Direct vs. indirect influence of Mayan on Yucatan Spanish}

In previous sections we have seen that Mayan is in a position to have influenced the Spanish of Yucatan, as well as statistical results showing both that Mayan-speakers and older speakers (exposed to more Mayan and Mayan-influenced Spanish) produce more stop variants than younger, monolingual speakers of Spanish do. These facts indicate that Mayan influence has played a role in the pattern of $/ \mathrm{b} \mathrm{d} \mathrm{g/} \mathrm{in} \mathrm{YS.} \mathrm{Can} \mathrm{we} \mathrm{say,} \mathrm{however,} \mathrm{that} \mathrm{the} \mathrm{stop} \mathrm{pattern} \mathrm{is} \mathrm{'due'}$ specifically to Mayan influence? Proponents of language-internal arguments for YS stops frequently cite a similar pattern in other varieties of Spanish that have no contact with Mayan. The extension of stops in other dialects, therefore, could not have been influenced by that language, but instead, it is argued, must have arisen due to mechanisms internal to Spanish. For example, Cassano (1977:100) cites similar stop patterns in Andean and Central American Spanish, as well as in some parts of Mexico, when arguing against a contact basis for [b d g] in YS. In Latin America, stops in place of fricatives are reported among bilingual speakers in Bolivia, Peru, the Esmeraldas region of Ecuador, the Andean region of Venezuela, and in Paraguay, among indigenous speakers in the Amazon region of Colombia, as well as rural zones of Costa Rica and Nicaragua, El Salvador, and Honduras (Lipski 1994). Outside of Latin America, stops [b d g] are often preferred in Equatorial Guinea (Lipski 1985), and are features commonly found among non-native students of Spanish language in the United States. This is usually attributed to first language (L1) English interference (Dalbor 1980, Teschner 2000, among others). Importantly, what previous studies on YS fail to notice is that the stop-preferring areas are or were characterized by large numbers of bilingual speakers, primarily of indigenous languages (or English, in the case of L2 learners in this county). Given the rarity of Iberian-style stop-fricative patterns cross-linguistically, it appears that the alternation fails to surface whenever Spanish comes into contact with a language that does not share the same phonological process, regardless of what that language is. Higher frequencies of stops have arisen in contact with Native American, West African, and other European languages (i.e., English). That is, it is not contact with Mayan per se, but instead long-term bilingualism and language contact itself that is responsible for the observed pattern in YS. Returning to the initial research question, whether the observed pattern for / $\mathrm{b} \mathrm{d} \mathrm{g/} \mathrm{in} \mathrm{YS} \mathrm{is} \mathrm{due} \mathrm{to} \mathrm{language} \mathrm{contact} \mathrm{with} \mathrm{Mayan,} \mathrm{the} \mathrm{answer} \mathrm{is} \mathrm{'yes',} \mathrm{but}$ 
only in the sense that Mayan happens to be the language with which YS is in contact. In other words, it is language contact, and not the Mayan language itself, that is responsible for the high rates of stops in YS.

The case of voiced stops in YS (and probably elsewhere), then, is best characterized as the result of what Thomason (2001: 74-75) calls 'imperfect learning' or substratum influence. Winford (2003: 15) notes that one of the possible scenarios for language shift of this type is that in which a linguistic minority imposes their language on a conquered majority, producing an "indigenized" variety of the target language. This new variety will reflect the difficulty the shifting speakers had in mastering the new language, in this case Spanish. In Yucatan, generations of Mayan-speakers failed to acquire a native Spanish pattern of stop-fricative alternation, a process that was hindered not only by their native Mayan phonology but also by the Mayan-accented input to which children acquiring Spanish were exposed. Thus, based on their L1 phonology, Mayan-speakers would have had difficulty perceiving and/or producing the monolingual Spanish pattern, conforming instead to the reanalyzed L2 system employed by other bilingual speakers (cf., Winford 2003: 245). Given adequate numbers of shifting speakers over a long period of language contact and incomplete bilingualism (in the sense that speakers are dominant in one of the languages in contact), linguistic features previously restricted to bilingual L2 speakers of Spanish can spread to the monolingual population. This is precisely the situation found in YS. Bilingual speakers produce significantly more stops than monolingual speakers of Spanish in Yucatan, but monolinguals also use stops more than speakers in other, non-contact areas. Importantly, the pattern seen in YS is not a case of 'anything goes' linguistic change brought about by contact with Mayan. Rather, it is the extension of a phonological rule already extant in monolingual Spanish (or, alternatively, the preservation of an archaic feature, [cf., Canfield 1981]) under the indirect influence of a shifting Mayan-speaking majority. Thus, the phonetic context that licenses stops is extended from following nasal consonants to following any consonant, with /s/ /l/ /r/ as particular standouts.

\section{Conclusions}

In conclusion, the present study shows that the observed pattern of stop [b d g] in YS is due to intense language contact (Mayan and Spanish) and the resulting centuries-long bilingualism. The non-native acquisition of a subtle Spanish allophonic alternation by a Mayanspeaking majority led to the preference for a simplified system favoring one variant (i.e., stops). Aspects of this reanalyzed (bilingual) system were then passed on, through daily contact with bilingual speakers and the processes of leveling and accommodation, to the monolingual elite. We cannot say, however, that the use of voiced stops is due to the direct influence of the Mayan language on Spanish, since Mayan does not natively possess these sounds, as evidenced by similar patterns in other bilingual regions. An extended context for stops, rather, is indicative of L2 Spanish around the world. In long term bilingual contexts, the preference for use of stop [b d g] may become fossilized throughout the speech community. This study demonstrates, therefore, that in some cases linguistic features that have been attributed to direct cross-linguistic influence are more correctly defined as L2 interference via shifting bilingual speakers, instead of being directly attributable to phonological transfer between languages. The case of $[\mathrm{b} \mathrm{d} \mathrm{g}]$ in YS lies between the extreme positions found in previous studies of either direct Mayan influence or strictly internal development. After generations of relative stability, however, the strong preference for fricatives among younger speakers indicates that this feature of YS (along with other regional traits, cf., Michnowicz 2006) may disappear from the dialect within a generation or two, as younger speakers adapt to pan-Hispanic standardized norms. Future research is needed to know for sure the fate of $[\mathrm{b} \mathrm{d} \mathrm{g}]$ stops in Yucatan. 


\section{References}

Alvar, M. (1969): "Nuevas notas sobre el español de Yucatán,” in: Iberoromania, I, 159-189.

Bailey, Guy. (2002): "Real and apparent time," in Chambers, J.K, Trudgill, P., \& Schilling-Estes, N. (eds.): The handbook of language variation and change. Oxford, UK: Blackwell, 312332.

Barrera Vásquez, Alfredo (1937): "Mayismos y voces mayas en el español de Yucatán," in: Investigaciones Lingüísticas 4, 9-35.

Bolles, D./Bolles, A. (2001): A grammar of the Yucatecan Mayan language. Lancaster, CA: Labryrinthos.

Canfield, D.L. (1981): Spanish pronunciation in the Americas. Chicago: The University of Chicago Press.

Cassano, P. (1977): "La influencia del maya en la fonología del español de Yucatán," in: Anuario de letras $15,95-113$.

Dalbor, J. (1980): Spanish pronunciation: Theory and practice (2nd ed.). New York: Harcourt Brace Jovanovich.

Hualde, J.I. (2005): The sounds of Spanish. New York: Cambridge University Press.

Instituto Nacional de Estadística, Geografía e Informática (INEGI) (2005): Conteo de población y vivienda 2005. http://www.inegi.gob.mx (October 4, 2007).

Lass, R. (1997): Historical linguistics and language change. Cambridge, UK: Cambridge University Press.

Lipski, J. (1985): The Spanish of Equatorial Guinea: the dialect of Malabo and its implications for Spanish dialectology. Tubingen, Germany: Niemeyer.

Lipski, J. (1994): Latin American Spanish. New York: Longman.

Lope Blanch, J. M. (1987): Estudios sobre el español de Yucatán. Mexico City, Mexico: Universidad Autónoma de México.

Mediz Bolio, A. (1951): Interinfluencia del maya con el español de Yucatán. Merida, Mexico: Editorial Zamna.

Michnowicz, J. (2006): Linguistic and social variables in Yucatán Spanish. Doctoral thesis. University Park, PA: Penn State University.

Mosely, E. H. (1980): "From conquest to independence: Yucatan under Spanish rule,

1521-1821," in Mosely, E./Terry, E. (eds.): Yucatan: A world apart. Alabama: University of Alabama Press, 83-121.

Nykl, A. R. (1938): "Notas sobre el español de Yucatán, Veracruz y Tlaxcala," in: Henríquez Ureña, P. (ed.): El español en Méjico, Los Estados Unidos, y la América Central. Buenos Aires: Editorial Universidad de Buenos Aires, 207-225.

Ola Orie, O./Bricker, V. R. (2000): "Placeless and historical laryngeals in Yucatec Maya," in: International Journal of American Linguistics 66(3), 283-317.

Penny, R. (2002): A history of the Spanish language. Cambridge, UK: Cambridge University Press.

Posner, R. (1996): The Romance languages. New York: Cambridge University Press.

Robinson, J./Lawrence, H./Tagliamonte, S. (2001): GoldVarb 2001 (Version 1.0.2.13) [Computer software]. http://www.york.ac.uk/depts/lang/webstuff/goldvarb (March 14, 2007).

Solomon, J. (1999): Phonological and syntactic variation in the Spanish of Valladolid, Yucatán. Doctoral thesis. Palo Alto, CA: Stanford University.

Suarez, V. M. (1979) [1945]: El español que se habla en Yucatán: Apuntamientos filológicos (2nd ed.). Merida, México: Universidad de Yucatán.

Teshner, R. V. (2000): Camino oral: fonética, fonología y práctica de los sonidos del español (2nd ed.). New York: McGraw Hill.

Thomason, S. G. (2001): Language contact: An introduction. Washington, DC: Georgetown University Press. 
Thomason, S. G./Kaufman, T. (1988): Language contact, creolization, and genetic linguistics. Berkeley: University of California Press.

Winford, D. (2003): An introduction to contact linguistics. Oxford: Blackwell

Yager, K. (1982): Estudio del cuadro consonántico del español de Mérida, Yucatán con consideraciones de posible influencia maya. Master thesis. Santa Barbara: University of California. 